Steffen Wöll

The West and the Word 


\section{Dialectics of the Global}

Edited by

Matthias Middell

Volume 13 


\section{Steffen Wöll}

\section{The West \\ and the Word}

Imagining, Formatting, and Ordering the American West in Nineteenth-Century Cultural Discourse

\section{DE GRUYTER \\ OLDENBOURG}


Funded with help of the DFG, a product of SFB 1199.

ISBN 978-3-11-069000-2

e-ISBN (PDF) 978-3-11-069013-2

e-ISBN (EPUB) 978-3-11-069024-8

ISSN 2570-2289

\section{Library of Congress Control Number: 2020940531}

Bibliographic information published by the Deutsche Nationalbibliothek

The Deutsche Nationalbibliothek lists this publication in the Deutsche Nationalbibliografie; detailed bibliographic data are available on the Internet at http://dnb.dnb.de.

(C) 2020 Walter de Gruyter GmbH, Berlin/Boston

Cover image: Mural by Emanuel Leutze (1816-1868), “Westward the Course of Empires Takes Its Way" (6.1 x 9.1 m), 1862. U.S. Capitol, House Wing, west stairway.

Typesetting: Integra Software Services Pvt. Ltd.

Printing and binding: CPI books $\mathrm{GmbH}$, Leck

www.degruyter.com 